\title{
Promoting usage of ICT in Open and Distance Education Programs
}

\author{
Dr. G. Vasudevaiah ${ }^{1 *}$
}

\section{ABSTRACT}

The idea of widening access to education, promoting independent and lifelong learning and adopting new methods to delivery of education is prominent in the goals of education in India. To facilitate human resource development in the country and widen access to education at all levels, the educational policy of the country has emphasized the promotion of use of ICT in its distance education programs. With the support of information and communication technology, thousands of people from remotest parts of countries have been able to access education through distance learning. The traditional method of education occurs in personal contact between the teacher and the learner in the classroom setting. This is anchored in the reality that teaching and learning take place at same time and same place. With the introduction of communication technology it has became clear that formal, informal or non-formal teaching and learning at the higher level could also be done via technology. This paper focuses on the concept of ICT and how it useful in open and distance learning and also discusses about various problems in usage of ICT in open and distance learning.

Keywords: Open And Distance Learning, ICT, Learning Methods.

In distance learning system, learners are crucial to the institution and are in large scale. It is difficult for a learner to visit the institution every day to get a service/support as available in a conventional system and at same time, it is even difficult to the institution itself to provide various services to the learners at different stages of a student learning life cycle, due to limited human resource available. Information and Communication Technology (ICT) is a prime resource to overcome such barriers. Information and communication technology is group of technologies by which various support services shall be provided at different phases of student learning life cycle in distance learning. The various phases are the admission phase, the learning phase, the evaluation phase and the certification phase.

\footnotetext{
${ }^{1}$ Teaching Assistant, Dept. of Adult, Continuing Education \& Extension, Sri Krishnadevaraya University, Ananthapuramu, India

*Responding Author

(C) 2016 I G Vasudevaiah; licensee IJIP. This is an Open Access Research distributed under the terms of the Creative Commons Attribution License (http://creativecommons.org/licenses/by/2.0), which permits unrestricted use, distribution, and reproduction in any Medium, provided the original work is properly cited.
} 


\section{Concept of Information and Communication Technology}

Information and Communication Technology (ICT) has become most widely used instrument. It has influenced all walks of life of human beings. ICT is the modern method of gathering, storing, manipulating, processing and communicating desired types of information in a specific environment. 'Computer technology' and 'Communication technology' are two main supporting pillars of this technology and the impact of these two in the information storage and dissemination is crucial. It is impossible to reduce its importance in the educational, cultural, agricultural, scientific and technical aspects of the world. Information needs are increasing day by day and in the present day society, every person is intending to be information oriented. Information technology has geared up the advancement of major technological innovations. Introduction of ICT has influenced very significantly the work culture not only in our country but also throughout the world. The advancements in the ICT have also brought the offices to home as their work-places. Most of the organizations are changing beyond their own expectations with the help of ICT taking decisions in a more scientific way. Thus fast technological changes definitely accelerate development in all directions.

\section{Advantages of ICT in Distance Education Sector}

The advantages of using ICT in distance education system are as follows:

1. Faster and flexible course delivery: ICT technologies have made it possible to deliver lessons/courses in a faster and easier manner in distance education by using computer-based or internet-based technologies.

2. Improved and increased access: ICTs have the capable to expand access for higher education as well as secondary education among people. ICTs enables distance education institutions to provide knowledge within reach of all. ICTs provide the opportunity of conducting thousands of classes on hundreds of subjects and courses available anytime, at any place, as per the need and convenience of learners.

3. Enhanced pedagogical and course design skills: Pedagogy is the art and science of teaching. Pedagogical knowledge is essential while using ICTs in course delivery at any stage of education. ICTs offer flexibility in an organization and design of courses in a suitable and effective manner that facilitates development of knowledge, skills and competences among learners.

4. Educational administration and management: Various areas of educational administration and management require ICT help at different levels. At school and colleges, at universities, there are different programmes available for registration, digital record keeping of staff and students. Academic Management Information System (MIS), Financial Management Information System, Student or staff database and Examination data base are some examples.

5. Enhanced collaboration and interaction: Usage of ICTs encourages interaction and collaboration between teachers and learners, and among learners in distance education. 
Collaboration and interaction among students creates environment for learning. Communication tools like telephones, cell phone, SMS, online forums, chat, blogs, social media platforms and e-mail etc. can made communication and discussion for meaningful learning experience among learners.

6. Preparation of teaching learning materials: With the use of word processing programmes ICTs are helpful for teachers in preparing their own instructional and visual materials. Programmes like Power Point, Paint and Photoshop help teachers to prepare various instructional materials. Internet provides a lot of material and information in searching required subject matter or helping aid.

7. Library and information service: Library and information services are very essential for academic process of an educational institution. Majority of educational institutions arrange ICT facilities in library services for teachers and students accessibility. Bibliographical searches for instructions, learning and research work, accessing online database and repositories. Internet has made library services easier, faster and more efficient.

8. Evaluation: Sending online assignment, questionnaires and submitting responses online, participating in discussion, blogs are modern approaches of evaluations which are being applied successfully with the help of ICTs. MOOCs are one of the best examples for this kind of online learning and evaluation.

9. Research: Research includes Formulation of hypothesis, Preparation of objectives, Data collection, Interpretation and analysis and Reporting as important areas. E-mail, computer programs like MS Word, MS Excel, and Statistical Package for Social Sciences (SPSS) are very useful technologies in the research. Literature review can be performed easily by using online search engines and Meta search engines.

\section{CHALLENGES TO ICT IN OPEN AND DISTANCE EDUCATION PROGRAMMES:}

There is evidence of some technological breakthrough that will support e-learning for distance education. There are however persistent in country challenges which must be noted if the country can make good progress in the promotion of e-learning.

Access to information and communication technology facilities still remains highly inadequate and distributed not equally throughout the country.

The capacity of teachers and educators to manage e-learning programs still remains low. While some do not have the adequate sills, others are averse to using ICT.

There is inadequate collaboration between the various stakeholders and agencies to check duplication and efficient utilization of the few available ICT resources.

There is insufficient equipment and slow Internet connectivity in most parts of the country.

There is also unreliable access to electricity in our country etc. 


\section{CONCLUSION}

There are many critical issues surrounding e-learning in distance education that need to be addressed in order to fulfill e-learning objectives. These include: Widening access to educational opportunities; enhancing the quality of learning; and reducing the cost of distance education. Elearning is, in all its forms, a relatively recent phenomenon in tertiary education that neither has not radically transformed teaching and learning practices nor significantly changed the access, costs, and quality of tertiary education. As this paper has shown, e-learning has grown at a rapid pace and has enhanced the overall learning and teaching experience in developed countries with less use demonstrated in developed countries, like India, due to high cost of power generation and access to ICT facilities. While e-learning has not lived up to its most ambitious promises to stem radical innovations in the pedagogic and organizational methods of the tertiary education, it has quietly enhanced and improved the traditional learning processes. Most of the organizational and institutions, especially in developing countries like India, are still in the early phase of elearning adoption, characterised by important enhancements of the learning process but no radical change in learning and teaching. Hence, if we give more importance to ICT in Open and Distance Education Programmes, learners can benefit the fruits from e-learning.

\section{REFERENCES}

A. Murali M Rao, “ICT in Open Distance Learning: Issues and Challenges”.

B. Abdon, R. Raab and S Ninomiya, "E-learning for international agriculture development:

Dealing with challenges”, International Journal of Education and Development using ICT, Vol. 4(1), 2008.

D. Anand, "Re-organizing universities for the information age", The International Review of Research in Open and Distance Learning, Vol. 8(3), 2007.

Kenneth Addah, Desmond Kpedu and Olivia A. T. Frimpong Kwapong, "Promoting E-Learning in Distance Education Programs in an African Country”. www.intechopen.com

M. Kim, "Factors influencing the acceptance of e-learning courses for mainstream faculty in higher institutions”, International Journal of Instructional Technology and Distance Learning, Vol. 5(2), 2008. (5).

Pradeep Kumar, "Advantages of Information and Communication Technologies in Distance Education Sector”, IJARIIE, Vol.2, Issue.1, 2016. ISSN 2395-4396 pp 10-15.

S. Imel and E. Jacobson, "Distance education and e-learning: New options for adult basic and English language education”, Research Digest, Vol. 4, 2006.

S. L. Mahajan, "Information Communication Technology in Distance Education in India: A Challenge”, Indian Journal of Open Learning, 2002, 11(2), ISSN 0971-2690 pp 269-277.

Yusuf, M. O. "Problems and Prospects of Open and Distance Education in Nigeria", Turkish Online Journal of Distance Education, 7(1), 2006, pp 22-29

How to cite this article: G Vasudevaiah (2016), Promoting usage of ICT in Open and Distance Education Programs, International Journal of Indian Psychology, Volume 3, Issue 3, No. 11, DIP: 18.01.197/20160303, ISBN: 978-1-365-21307-6 